\title{
PCC em pauta: Narrativas jornalísticas sobre a expansão do grupo pelo Brasil
}

Thais Lemos Duarte

Universidade Federal de Minas Gerais, Belo Horizonte, MG, Brasil

Isabela Cristina Alves de Araújo

Universidade Federal de São Carlos, São Carlos, SP, Brasil

\begin{abstract}
A expansão do Primeiro Comando da Capital pelo país não foi suficientemente considerada nos estudos acadêmicos sobre o tema, tampouco foram examinados os efeitos da atuação do grupo no território mineiro. Embasando-se na concepção de Misse (1999, 2008) sobre acumulação social da violência, a proposta do texto é analisar como jornais de grande circulação tratam ambas as questões. Neste sentido, foram sistematizadas matérias da Folha de S. Paulo e O Tempo, lançadas entre 2005 e 2017, relacionadas à ação do PCC. Foi possível estudar, assim, o processo de difusão da organização paulista pelo Brasil e por Minas Gerais.
\end{abstract}

Palavras-chave: imprensa, organizações criminais, Primeiro Comando da Capital, expansão, Minas Gerais
The expansion of the First Command of the Capital (PCC) throughout Brazil was not sufficiently considered in academic studies, nor were the effects of the group's actions in the Minas Gerais' territory. Based on Misse's $(1999,2008)$ conception of social accumulation of violence, the proposal of PCC on the Agenda: Journalistic Narratives about the Group Expansion through Brazil is to analyze how widely circulated newspapers deal with both issues. In this sense, articles from Folha de S. Paulo and O Tempo, launched between 2005 and 2017, related to the action of the PCC, were systematized. It was possible to study the process of diffusion of the São Paulo organization throughout Brazil and Minas Gerais.

Keywords: media, criminal organisations, First Command of the Capital, expansion, Minas Gerais

\section{Escopo da questão ${ }^{1}$}

A violência urbana se tornou, ao longo das últimas décadas, pauta central do debate público. A imprensa, os estudos acadêmicos, a gestão pública e a sociedade civil voltaram-se atentamente à questão, empreendendo esforços para traçar ações das mais variadas naturezas, algumas de cunho fortemente repressivo, outras de caráter mais garantidor de direitos. Nesse mote, o tráfico de drogas e, por sua vez, as organizações criminais, como o Primeiro Comando da Capital (PCC), se tornaram protagonistas ${ }^{2}$. Não são poucos os debates e as disputas em torno do assunto, centrados na compreensão do modus operandi desses grupos, e as proposições de medidas para reprimi-los e preveni-los.

A imprensa apresenta papel fundamental nesse cenário, fomentando o que Misse (1999, 2008) identificou como "acumulação social da violência" ${ }^{3}$. Esse processo designa um complexo de fatores, uma síndrome, que envolve circularidade causal acumulativa. Não seria possível esgotar a construção social do crime apenas via criminalização, acatando meramente os conceitos prescritos pelo direito vigente. Iniciado na década de 1950 e estendendo-se até os dias atuais, o 
fenômeno se tornou típico na cidade do Rio de Janeiro e em seus arredores, tendo alcançado, porém, outros municípios, capitais, estados e talvez todo o país ao longo dos anos.

Tendo isso em vista, Misse $(1999,2008)$ propôs uma análise complexa, abrangendo quatro diferentes estágios relativos à "acumulação social da violência", não necessariamente concatenados cronologicamente entre si. O primeiro deles versa sobre a criminalização de um encadeamento de práticas baseada em uma construção típico-ideal, cuja função é definir o comportamento criminoso. É geralmente produto de uma campanha pública vitoriosa ou resultado da tradição, embasando-se na resposta social fornecida ao curso de ação tipificado como crime, institucionalizada em sanções penais. O segundo estágio diz respeito à criminação, expressa na subsunção do encadeamento de atos à classificação criminalizadora. Nada mais é do que a identificação de determinado fato como crime. O terceiro estágio corresponde à incriminação do sujeito analisado como autor do evento criminoso, graças a testemunhos e demais evidências relacionadas a certo caso. Por fim, no quarto estágio inicia-se a sujeição criminal.

Esse último estágio resulta da formação de subjetividades, identidades e subculturas. Misse (1999) afirma que o primeiro fator necessário a esse processo diz respeito à elaboração de designações sociais, cujo objetivo é a exclusão criminal de indivíduos que se encaixam na classificação social de determinado delito. $\mathrm{O}$ segundo fator se relaciona a certo tipo de trajetória de vida individual que expressa uma tendência à prática de crimes. Finalmente, o terceiro fator é a presença de autorrepresentações existentes no próprio indivíduo, ou em sua família, ou em outros tipos de relações significativas, que buscam justificar as práticas e as escolhas pessoais. A ausência de um desses três elementos excluiria um indivíduo da situação de sujeição criminal, porém não impossibilitaria sua incriminação. Esta, portanto, seria uma condição necessária, mas não suficiente, para a sujeição.

Esse conceito proposto pelo autor seria uma espécie de aprofundamento da abordagem do

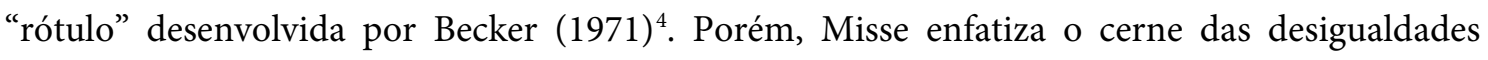
estruturais, uma vez que, para analisar o contexto brasileiro, considera fundamental salientar a existência de um ordenamento hierárquico e de um ordenamento individualista de sociedade que, associados às fortes desigualdades econômicas, radicalizam o processo de rotulação (MISSE, 1999). Dessa forma, o conceito de sujeição criminal pode ser considerado uma adaptação da teoria de Becker (1971) ao cenário nacional.

Todo os processos relacionados à criminalização social implicam a existência de um intérprete virtual, um acusador último que, em rodízio, ocupará várias posições, mas restará sempre crente de que ele próprio não será incriminado e, no limite, sujeitado (MISSE, 2008). Este texto parte da ideia de que a imprensa em boa medida cumpre esse papel, acumulando a função de caracterizar atos socialmente identificados como criminosos, divulgá-los e pautar as ações a serem empreendidas por órgãos de controle do Estado. A imprensa ajudaria, então, a reforçar a 
desigualdade que perfaz todo o sistema de crenças a respeito da incriminação no Brasil e que caracteriza a "sensibilidade jurídica" de todas as classes sociais (Ibid., p. 382). Essa hierarquização das relações se articula cada vez mais com o sentimento de insegurança e a concepção da incriminação baseada na sujeição criminal.

Não são poucas as matérias de jornais que noticiam a ação do PCC, sobretudo nos últimos anos, em que houve indícios da expansão do grupo a localidades distintas de seu território de origem, São Paulo. Nesse sentido, a proposta deste artigo é analisar como a imprensa retrata a difusão do PCC pelo Brasil, em especial em Minas Gerais. Porém, antes do exame do conteúdo das matérias veiculadas pela imprensa sobre o tema, apontaremos os passos metodológicos adotados na pesquisa e faremos uma revisão da literatura sobre o PCC.

\section{Percurso metodológico}

Realizamos um clipping de notícias em dois jornais de grande circulação no país, um de São Paulo, a Folha de S. Paulo, e outro de Minas Gerais, $O T e m p o^{5}$. A literatura sobre o PCC aponta que o marco de consolidação e propagação do grupo para dentro e para fora das prisões de São Paulo ocorreu em 2006. Portanto, o clipping realizado compreendeu o período de $1^{\circ}$ de janeiro de 2005 a 31 de dezembro de 2017, o que possibilitou a análise de matérias veiculadas na imprensa um ano antes da indicação temporal das referências bibliográficas. As análises descritas neste artigo compreenderam, então, um intervalo de doze anos, abrangendo o período identificado de disseminação da organização.

Para a realização do levantamento de matérias nos acervos dos jornais, foram utilizadas duas palavras-chaves, cada qual pesquisada separadamente: "PCC" e "Primeiro Comando da Capital". Tentamos conjugar os dois termos com outros adicionais, como "rotas", "drogas", "grupo criminoso", "prisões" etc. Entretanto, como os sites pesquisados permitiam a busca de somente uma palavra por vez, a saída foi usarmos os termos que necessariamente apareceriam em matérias sobre a organização criminosa, como o seu próprio nome. Foram feitas procuras exploratórias com os demais termos e notamos que as reportagens levantadas já tinham sido abarcadas nas consultas anteriores, nas quais foram utilizados os termos "PCC" e "Primeiro Comando da Capital".

Não foram abrangidas colunas de opinião, tampouco editoriais. Concentramo-nos em matérias de jornais, das mais reduzidas às mais completas. Inclusive, coletamos notícias que apenas mencionavam pontualmente o PCC, o que permitiu compreender o tipo de abordagem sobre o grupo fornecido pelos jornais. 
Ao fim do levantamento, foram sistematizadas 3.008 reportagens, sendo 2.001 da Folha de $S$. Paulo e 1.007 d'O Tempo. Todos esses documentos foram dispostos em uma base de dados que contemplou as seguintes variáveis: nome do jornal, data da matéria, manchete da reportagem e caderno. Apenas foi possível coletar informações sobre o número de página das matérias de $1^{\circ}$ de janeiro de 2005 a 31 de dezembro de 2017. Como esse dado não estava disponível para as matérias d'O Tempo, não foi levado em consideração.

O material analisado não permite compreender a cobertura oferecida pelos jornais sobre o PCC em comparação às suas demais pautas. Para isso, teriam de ser levantadas todas as matérias lançadas por ambos os veículos no recorte temporal em questão, independentemente de seu teor, o que poderia dificultar ou mesmo inviabilizar a realização da pesquisa. Em contrapartida, pelas informações levantadas é possível compreender o tipo de cobertura oferecido pela imprensa sobre o PCC ao longo do tempo, bem como as fontes de informação utilizadas, o grau de atenção à questão, a forma como a imprensa retrata o processo de expansão do grupo pelo Brasil, entre outros aspectos importantes ao estudo de organizações criminais. Tentaremos responder essas questões nas próximas seções.

\section{Dinâmicas de ação do PCC}

Desde o final da década de 1980, houve o fortalecimento de uma orientação militarizada de controle criminal no Brasil, o que ficou evidente no episódio de repercussão internacional conhecido como Massacre do Carandiru, ocorrido em 1992 na cidade de São Paulo (PASTORAL CARCERÁRIA, 2016). A polícia assumiu o protagonismo da "repressão ao crime", atuando na lógica da eliminação do inimigo, principalmente o "traficante de drogas". O resultado desse tipo de ação foi a flagrante elevação da letalidade policial, sendo relegado ao segundo plano o trabalho de caráter mais investigativo (SILVESTRE, 2016).

Somado a isso, Silvestre ( Ibid.) indica que interesses econômicos e políticos fomentaram um movimento de interiorização das unidades prisionais, sendo essa medida muito característica do estado de São Paulo. A década de 1990, fase de aprofundamento do processo de interiorização penitenciária, foi marcada por estagnação e crise em vários setores da economia, materializadas, sobretudo, em desemprego. Para São Paulo, todavia, a construção de unidades prisionais no interior gerou mais de 18.000 postos de trabalho, resultantes de investimentos, à época, de mais de 230 milhões de reais (Ibid.). As cidades receberam um retorno financeiro direto por meio da construção de cárceres ${ }^{6}$.

A pulverização das prisões para o interior do estado evitou o impacto visual causado pelo crescimento da população carcerária, camuflando a política de encarceramento em massa 
(BIONDI, 2010). Isto é, a superlotação prisional e as péssimas condições de aprisionamento não pareciam ser um problema social, passando despercebidas para a população em geral. Por outro lado, a intensificação da construção de novas prisões não atendeu ao grande número de pessoas encarceradas. Enquanto a população paulista cresceu 5,3\% de 2003 a 2007, a população prisional cresceu 23,4\% no mesmo período (SALLA et al., 2012). Foi nesse contexto que o PCC se desenvolveu. $\mathrm{O}$ encarceramento em massa forneceu bases para o nascimento e a consolidação do grupo que, para além de realizar atividades criminosas, assumiu um protagonismo na gestão da violência nas prisões e nas periferias. Quanto mais o PCC se expandia, mais o governo investia na ampliação de um sistema que o nutria (FELTRAN, 2013).

Conforme Dias (2011), o grupo foi fundado em 1993, durante uma rebelião no Centro de Reabilitação Penitenciária, anexo da Casa de Custódia e Tratamento de Taubaté, em São Paulo ${ }^{7}$. Desde então, até 2001 o grupo passou por intensa expansão no sistema prisional paulista, sendo a violência física instrumento central ao processo. O PCC travou lutas ferozes na disputa de territórios e pela adesão de novos membros por meio dos "batismos", cerimônias em que o indivíduo adere às normas do grupo e se torna um membro. Não à toa, a espetacularização da força foi fundamental para a demonstração e manutenção de poder do PCC. Além da expansão para prisões locais, a organização conformou um código de conduta de importância simbólica entre os presos, como a regulação dos estupros, por exemplo (DIAS, 2011).

Esse processo de difusão no sistema prisional paulista ocorreu nos subterrâneos dos cárceres, pois a violência expressiva não era exposta à população em geral, tampouco era admitida pela gestão pública (Idem). No entanto, esse cenário começou a se reconfigurar em 2001, quando houve uma megarrebelião nas prisões estaduais. Nesse momento, o PCC já tinha garantido uma estrutura sólida de atuação e boa capacidade de planejamento, articulando sua expansão para fora dos muros dos estabelecimentos prisionais (FELTRAN, 2010). Para tanto, o grupo readequou sua tática inicial: se sua primeira fase de formação foi marcada por ações violentas, nessa segunda havia certa oscilação em relação ao uso da força.

Dias (2011) indica que o efeito dessa nova etapa foi duplo, ocasionando tanto a "disseminação" da organização como um reforço da "repressão". Por um lado, ensejou o aumento do controle executado por órgãos do sistema de justiça criminal sobre o grupo — não à toa, o Regime Disciplinar Diferenciado $(\mathrm{RDD})^{8}$ foi implantado no período. Por outro, conferiu prestígio e respeito a membros do PCC, o que fortaleceu e impulsionou sua dispersão por todo o estado de São Paulo.

Esse quadro foi crucial para a entrada do PCC em sua terceira fase (DIAS, 2011). Esse momento foi inaugurado por megarrebeliões deflagradas em diversas prisões paulistas ao longo de 2006, especialmente, em maio daquele ano. Cárceres, postos, viaturas, delegacias de polícia e diversos outros tipos de prédios públicos sofreram ataques armados, cujos principais alvos 
eram policiais e agentes penitenciários (CANO e ALVADIA, 2008). A polícia então reagiu. As folgas e férias dos policiais foram canceladas e todo o efetivo foi posto nas ruas. Entre 12 e 21 de maio de 2006, na chamada "semana sangrenta", centenas de pessoas foram mortas. A violência excessiva das ações policiais e a explícita atividade de grupos de extermínio causaram grande preocupação à população.

Adorno e Dias (2016) apontam que os atentados de 2006 conformaram as relações de poder no sistema prisional, cuja base seria a acomodação entre a massa carcerária - sob a liderança do PCC - e a administração penitenciária. O Estado tinha se mostrado incapaz de conter possíveis motins comandados pelo grupo. Apenas o PCC poderia evitar tais eventos, "disciplinando" os presos conforme seus preceitos e valores. Em outras palavras, a hegemonia do PCC seria a condição necessária à manutenção da política penal executada pelo governo estadual, cujo mote central era - e ainda é - o encarceramento massivo de pessoas, ao passo que esse mesmo fenômeno, somado às péssimas condições de privação de liberdade, comporiam elementos essenciais ao fortalecimento do PCC (ADORNO e DIAS, 2016).

Desenvolveu-se, assim, uma simbiose entre ambos os atores, cujo efeito prático foi o estabelecimento de uma espécie de calmaria no sistema prisional paulista após 2006 (Idem). Praticamente desapareceu a expressão simbólica do poder presente durante o processo de expansão e consolidação do PCC pelas prisões e, ainda, nas periferias das cidades paulistas, com assassinatos cruéis e domínio fulminante (DIAS, 2011). Até mesmo porque, nessa terceira etapa, o grupo consagrou a sua hegemonia, consolidando-se como uma nova figura social dentro e fora das prisões paulistas.

Surgiram formas mais racionais de atuação, com execuções mais planejadas, circunscritas a questões específicas (MARQUES, 2009). Inclusive, os índices de homicídio do estado de São Paulo foram reduzidos a partir da consecução dos "debates" do PCC nas periferias, comumente identificado pela imprensa como "tribunais do crime" (DIAS, 2011; FELTRAN, 2010). O grupo teria monopolizado o emprego da violência legítima no "mundo do crime", alcançando a prerrogativa de controlar e regular as atividades ilícitas que compõem o núcleo da economia criminal paulista (LOURENÇO e DIAS, 2015).

Provavelmente, a consolidação do PCC dentro e fora das prisões possibilitou, entre outros aspectos, a disseminação do grupo em outros estados do Brasil, como Minas Gerais, e em outros países da América do Sul. Uma pesquisa ainda em andamento realizada pelo Centro de Estudos de Criminalidade e Segurança Pública (Crisp) da Universidade Federal de Minas Gerais (UFMG) apontou que dois pavilhões da Penitenciária Nelson Hungria, localizada na Região Metropolitana de Belo Horizonte (RMBH), alocariam aproximadamente 200 presos identificados pelo sistema de justiça criminal como pertencentes ao PCC. Eles seriam oriundos, 
sobretudo, do sul do estado e do Triângulo Mineiro. Ao que tudo indica, criariam regras de comportamento e uma divisão de tarefas totalmente distintas das estabelecidas no restante do universo prisional mineiro (OLIVEIRA et al., 2017).

Com esse problema em vista, nas próximas seções analisaremos como a imprensa retrata a ação do PCC fora do estado de São Paulo.

\section{Diagnóstico geral das notícias}

O gráfico abaixo indica o percentual de reportagens veiculadas entre janeiro de 2005 e dezembro de 2017 sobre o PCC nos dois jornais em análise.

Gráfico 1: Evolução de notícias de jornais sobre PCC entre 2005 e 2007

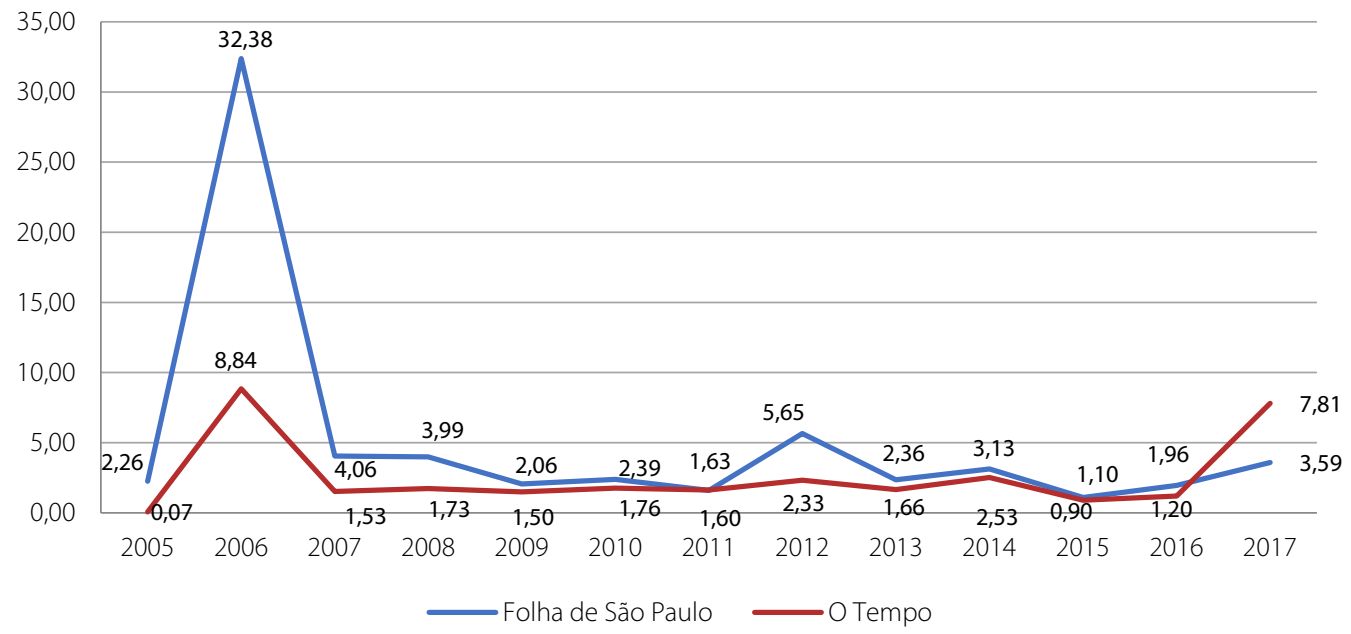

Fonte: Folha de S. Paulo e O Tempo (janeiro de 2005 a dezembro de 2017).

Uma primeira interpretação a se depreender do Gráfico 1 refere-se ao fato de o PCC ter sido pauta constante em ambos os jornais no período compreendido, ainda que em alguns momentos mais, em outros menos. Não há grandes distanciamentos entre os conteúdos das reportagens produzidas pela Folha de S. Paulo e pelo jornal O Tempo. Em geral, ambos lançaram matérias bastante superficiais sobre a ação do PCC, não se propondo, na maioria das vezes, a uma complexificação do debate. Muitas se fundamentaram em fontes produzidas por órgãos públicos, como denúncias do Ministério Público e relatos policiais. Não seria exagero sugerir, então, que a imprensa em boa medida ajuda a reproduzir e reforçar a narrativa do poder público sobre criminalidade e organizações criminais. Com efeito, contribui significativamente para a acumulação social da violência (MISSE, 1999, 2008), disseminando clivagens tradicionalmente 
operadas por órgãos do sistema de justiça criminal. O resultado desse processo seria, entre outros, a criminalização de grupos econômica e socialmente vulneráveis, como indivíduos pobres, negros e moradores de espaços periféricos (COELHO, 1978).

Essas informações costumam ser contrapostas ou reforçadas por análises fornecidas por especialistas em segurança pública, normalmente, operadores do direito e pesquisadores. Pessoas com perspectiva mais crítica às políticas executadas no âmbito prisional e de segurança pública são chamadas para contribuir em textos com tom mais voltado à garantia de direitos. Por outro lado, tal qual ocorre em um bom número de matérias, indivíduos mais adeptos ao modelo policial e prisional comumente imposto são chamados para cooperar em reportagens cujo teor reitera aquele produzido por órgãos do sistema de justiça criminal. Para esse segundo tipo de abordagem, não parece estar em jogo uma análise qualificada sobre a dita criminalidade, mas um fortalecimento da perspectiva criminalizante a determinadas populações.

Durante todo o corte temporal em análise, a Folha de S. Paulo produziu um maior número de reportagens sobre o PCC em relação a $O$ Tempo. Esse resultado era em alguma medida esperado, uma vez que o primeiro jornal, por ser paulista, costuma noticiar fenômenos do mesmo estado onde o PCC se originou e se consolidou. O pico de matérias sobre o grupo em ambos os jornais foi em 2006. Das matérias produzidas naquele ano, a maior parte era da Folha, que contemplou 33\% do total. Como dito, naquele ano o PCC deflagrou uma série de rebeliões em prisões e irrompeu diversos atentados em vários municípios de São Paulo. O mês de maio, momento em que os eventos foram mais intensos, abrangeu um terço das notícias de 2006. Esse número é relativamente semelhante nos dois jornais, já que maio abarcou 30\% das notícias sobre o PCC na Folha de S. Paulo e 33\% das reportagens n'O Tempo. Por outro lado, o número é bastante pequeno nos meses anteriores, correspondendo a menos de $4 \%$ do total de notícias sobre o grupo em ambos os jornais.

De igual maneira, foram veiculadas muitas matérias sobre o grupo em junho, julho e agosto de 2006, concentrando nesses meses 50\% das notícias de todo o ano. No período, ocorreram novas ações da organização em São Paulo, haja vista a demanda de que lideranças do PCC fossem retiradas do RDD, bem como a perpetuação de condições degradantes nas prisões (DIAS, 2011). Entretanto, nos meses subsequentes a agosto, o total de reportagens caiu substancialmente, atingindo aproximadamente $16 \%$ em ambos os jornais.

Ou seja, a pauta sobre o PCC ganhou força na ocasião imediata aos ataques, não sendo prioritária no momento anterior, tampouco no posterior. Ao fim de 2006, o número de reportagens reduziu de modo considerável tanto na Folha de S. Paulo quanto n'O Tempo, mantendo-se relativamente constante ao longo de alguns anos. O PCC continuou a ser pauta nos jornais, mas com menor ênfase. 
Apenas em 2012 o jornal paulista voltou a apresentar um pequeno pico de matérias em relação aos anos anteriores, aproximadamente 6\%, seguido de uma redução de notícias. Esse aumento pode estar conectado ao que Silvestre (2016) identificou como "crise de 2012", cujo elemento central foi uma "guerra" entre a polícia militar paulista e o PCC. O resultado desse evento foi o aumento no número de policiais assassinados, muitos com características de execução, bem como o crescimento de chacinas e de execuções sumárias no estado de São Paulo, sobretudo na capital e na região metropolitana. Com efeito, houve um crescimento das taxas de homicídio, tendência que não se configurava há mais de dez anos no estado (SILVESTRE, 2016). Segundo Dias et al. (2015), diferentemente do episódio de 2006, nesse caso a crise se prolongou durante boa parte do ano e caracterizou-se pela dispersão e pela fragmentação dos ataques.

Quantitativamente, o evento não gerou forte comoção n' O Tempo, apesar de ter entrado em pauta em algumas matérias da época, como será discutido adiante. O número de notícias nesse veículo não variou muito no período, correspondendo a 2,3\% das notícias dispostas na base de dados. Em contrapartida, 2017 se diferenciou de todos os demais da série. Em primeiro lugar, voltou a ocorrer um crescimento das notícias de jornais sobre o PCC; em segundo, pela primeira vez $O$ Tempo superou o número de reportagens da Folha de $S$. Paulo sobre o grupo. Esse momento correspondeu a um período de violentas rebeliões em unidades prisionais das regiões Norte e Nordeste do país, suscitadas por disputas entre a organização paulista e outros grupos criminais, como o Comando Vermelho (CV). O objetivo foi concorrer pelo domínio de novos territórios e, assim, aumentar o número de adeptos às organizações.

Talvez o jornal mineiro tenha dado mais destaque a esses episódios pelo fato de o PCC ter começado a ser pautado como uma preocupação local. Reforçando essa hipótese, ao analisar em que espaço a questão costumou ser tratada n'O Tempo, durante boa parte do recorte temporal observou-se que as matérias sobre o PCC foram expostas no caderno com abordagem nacional, designado "Brasil”. Entretanto, em 2017, o tema surgiu com mais força em seções voltadas a aspectos regionais, como o caderno "Cidades", parecendo se tornar uma questão mais próxima à realidade de Minas Gerais.

Em 20\% do universo de todas as reportagens analisadas em ambos os jornais, o nome da organização criminal estava explicitamente disposto em suas manchetes, o que novamente pode ser percebido como um indicativo do destaque dado ao tema pelos veículos de comunicação. Possivelmente, quanto maior o número de matérias em que o PCC é descrito em suas manchetes, maior é a atenção e, portanto, a projeção dada pela imprensa sobre o grupo.

Do conjunto de matérias da Folha de S. Paulo no período dos doze anos contemplados na pesquisa, $17 \%$ forneceram esse tipo de visibilidade ao grupo, sendo isso mais marcante em 2006, quando ocorreram os mencionados atentados coordenados pelo PCC. Aproximadamente 68\% 
das matérias em que o grupo foi deliberadamente citado na manchete do jornal se referiram a esse ano. Já em 2017, momento em que ocorreram as referidas rebeliões em diversas prisões do país, o grupo foi explicitamente indicado em apenas cerca de $9 \%$ dos títulos das reportagens.

No caso do jornal O Tempo, ao longo dos doze anos, o PCC foi citado nas manchetes em $29 \%$ das reportagens, uma proporção ainda maior em relação à Folha de S. Paulo. No entanto, contrariamente ao jornal paulista, $14 \%$ dos casos se concentraram em 2006, ao passo que essa proporção se ampliou para aproximadamente $25 \%$ em 2017. Esses dados indicam que o jornal mineiro deu significativa projeção ao PCC em anos mais recentes, em detrimento do paulista, o que reforça a hipótese de que $O$ Tempo estaria mais atento à expansão da organização para fora de São Paulo.

Nas seções a seguir, forneceremos elementos de natureza mais qualitativa sobre os jornais em análise.

\section{Fato a fato}

Uma das reportagens mais completas sobre a disseminação do PCC para fora do território paulista foi publicada somente no início de 2017 pela Folha de S. Paulo. Seu intuito foi explicar os motivos pelos quais ocorreram as rebeliões em prisões do Norte e do Nordeste do país, ocasionadas por disputas entre grupos criminosos, entre eles o PCC.

O grupo teria começado a se difundir ainda na década de 1990, a partir de transferências realizadas pela administração prisional de São Paulo para o Paraná. O objetivo foi dissolver lideranças de presos que fomentariam a consolidação da organização nos cárceres paulistas. Essa medida foi tomada com muita discrição pelas administrações prisionais estaduais, pois, à época, ainda não havia presídios federais9. A privação de liberdade foi designada para ser cumprida sob a égide de uma administração prisional diferente de onde um grupo de presos recebeu sua condenação.

Segundo o promotor paulista citado na reportagem, em vez de desarticular o grupo, a tentativa de dispersão de lideranças do PCC para outros territórios o fortificou, disseminando seus valores e códigos de conduta a outros locais.

O início do processo de migração do PCC, no entanto, foi estimulado irrefletidamente pelo governo paulista que, na tentativa de desarticular o movimento que ganhava força nos presídios do Estado, transferiu em 1998 os seus cabeças para o Paraná, numa operação cercada de discrição. "O efeito foi o contrário", diz o promotor Lincoln Gakiya, que atua na região Oeste do Estado (GENTILE, 16/01/2017). 
Não há muitas referências sobre essa transferência de presos do PCC ao Paraná na década de 1990 (CHRISTINO, 2001). Contudo, a Folha de S. Paulo ressaltou que a presença dessas pessoas no sistema prisional estadual provocou a criação do Primeiro Comando do Paraná, cujo estatuto foi apreendido posteriormente na Penitenciária Central do Estado, em Piraquara. Passado um tempo após a transferência, presos paranaenses amotinados exigiram do governo a volta dos custodiados paulistas a seu estado de origem.

De fato, a expansão do PCC pelo Brasil não era efetivamente pautada pela imprensa nos primeiros anos do período em análise. $\mathrm{O}$ tema parecia ser apenas uma possível preocupação, tanto que em 2006 algumas matérias indicavam que o poder público teria adotado medidas para evitar um "contágio" dos atos do grupo em outros estados além de São Paulo. A ideia era impedir que organizações criminais adotassem procedimentos parecidos com os conduzidos pelo grupo paulista. Portanto, na reportagem d'O Tempo intitulada "Rio se prepara para 'contágio" (O TEMPO, 16/05/2006), apontou-se que, apesar de não haver motivos para apreensão, a Secretaria de Segurança Pública do Rio de Janeiro reforçou o policiamento em algumas regiões próximas a presídios para se precaver de possíveis atos violentos no estado, tais como os ocorrido em São Paulo.

A imprensa ajudaria a atribuir uma espécie de identidade criminalizante a áreas e atores que não necessariamente tiveram contato com o PCC. Nesse sentido, justificaria ações do Estado voltadas ao uso da força, reforçando a perspectiva de Misse $(1999,2008)$. De fato, áreas onde presídios estão situados, como as descritas na reportagem supracitada, geralmente são apreciadas negativamente por grupos sociais. Isso porque um local onde são desenvolvidas atividades criminosas, ou que abarca pessoas ditas desviantes, tende a ser rejeitado socialmente (BECKER, 1971). Esse tipo de perspectiva sobre um dado território pode se radicalizar com a veiculação de notícias como a referida acima.

Um conjunto mais consistente de matérias sobre a dispersão do PCC pelo Brasil começou a surgir a partir de 2011, momento em que a Folha de S. Paulo indicou que o grupo teria o domínio de 17 estados. Entretanto, esses levantamentos pareceram flutuantes, pois dois anos depois disso o mesmo jornal afirmou que a organização estaria em 13 unidades da federação, sem fornecer explicações sobre a diferença entre os dados publicizados em ambos os momentos. Isto é, inexiste uma continuidade entre o conteúdo das distintas matérias ao longo do tempo. Em vez de se complementarem, podem ser contraditórias, ainda que pertençam a um mesmo veículo. Dias (2011) chamou a atenção para essas possíveis discrepâncias. Para a autora, a imprensa está em muitos momentos mais preocupada em lançar notícias em primeira mão do que em garantir uma informação sólida e concisa sobre os assuntos veiculados.

O jornal paulista também apontou no período de 2011 para uma possível interlocução entre o CV e a organização paulista, visto que o PCC forneceria drogas à facção carioca, adotando como centro de distribuição uma favela da Zona Norte do Rio de Janeiro (FOLHA DE S. PAULO, 
26/11/2011). Não obstante, os braços do PCC pareciam também ter incidido sobre territórios mais longínquos, tendo a Folha de S. Paulo indicado em uma reportagem de capa que o grupo teria criado um esquema internacional de tráfico de drogas, inserindo-se em áreas até então assumidas somente por traficantes considerados mais "experientes", como Fernandinho Beira-Mar, do CV.

\footnotetext{
A faç̧ão criminosa paulista PCC (Primeiro Comando da Capital) assumiu a venda de drogas a partir do Paraguai e da Bolívia para o Brasil, apontam investigações da polícia brasileira e de autoridades sulamericanas. Elas descobriram que, a partir desses países, o grupo abastece de maconha e cocaína o mercado nacional. A quadrilha é investigada ainda por se associar a traficantes internacionais e vender cocaína a Portugal, Alemanha e Itália, usando portos na Argentina, Uruguai e Chile para exportar a droga. O PCC também estaria envolvido na venda de drogas produzidas na Colômbia e no Peru, a partir da Bolívia. O crescimento da facção criminosa rumo ao exterior começou em 2008. Naquele ano, a organização percebeu a oportunidade de assumir o negócio com os produtores de maconha, no Paraguai, e de cocaína, na Bolívia. Até então, Luiz Fernando da Costa, o Fernandinho Beira-Mar, era um dos poucos criminosos que havia quebrado essa barreira (FOLHA DE S. PAULO, 19/12/2011).
}

Ainda em 2011, momento que a literatura aponta como de consolidação da hegemonia do PCC em São Paulo, a imprensa atribuiu ao grupo uma ação de abrangência internacional, dispondo sobre sua expansão não só aos vizinhos da América do Sul, mas também à Europa. Expondo fontes policiais, a Folha de S. Paulo pareceu maximizar a capacidade de atuação do grupo sem oferecer elementos sólidos sobre como a difusão do PCC era realmente exercida. Em suas reportagens, não são indicados detalhes sobre as dinâmicas criminais efetivadas, o perfil dos atores envolvidos ou outros aspectos essenciais para a compreensão mais aprofundada da questão.

Por certo, determinadas informações policiais podem ser consideradas sigilosas e, portanto, não devem ser expostas em páginas de jornais. Contudo, não fica explícito o motivo de se ventilar publicamente os territórios onde o PCC teria domínio sem indicar minimamente o seu modus operandi. Ao que tudo indica, parece haver um afã maior em fornecer elementos de cunho quase sensacionalista sobre o poderio do PCC, em detrimento do repasse efetivo de relatos sobre as consequências da sua ação a diferentes cenários. Não necessariamente são fornecidos elementos que possibilitam o processo completo de criminalização descrito por Misse $(1999,2008)$, sendo apenas lançados aspectos que potencialmente gerariam incriminações do grupo.

Meses após a divulgação do trecho da reportagem anterior, a Folha de S. Paulovoltou a insinuar a atuação do PCC em localidades fora do território paulista. Criou-se certa relação entre uma onda de atos violentos em Santa Catarina em novembro de 2012 e a organização criminosa. Com esse mote, foram lançadas as matérias "Crime cresce em SC com migração de quadrilhas" (FOLHA DE S. PAULO, 18/11/2012); "Facção pode ter ordenado ataques em Santa Catarina" (BÄCHTOLD, 19/11/2012). Nesta última, mencionou-se que os ataques nesse estado foram orquestrados pelo 
Primeiro Grupo da Capital (PGC), e não pelo PCC, apesar de haver semelhanças com os eventos ocorridos em São Paulo em 2006. Não fica clara a autoria dos acontecimentos, apesar de haver uma alusão à influência da organização paulista no território catarinense.

Em 2013, o mesmo jornal voltou a relacionar as atividades do PCC com facções criminais cariocas, indicando o estabelecimento de conexões refinadas entre as diferentes organizações - fato que, anos antes, era percebido apenas como uma possibilidade. O PCC gerenciaria negócios no Rio de Janeiro, por meio de parcerias com os Amigos dos Amigos (ADA), o Terceiro Comando (TC) e o CV. Com o mesmo argumento, outra reportagem assinalou que a influência do PCC era tão grande sobre o tráfico fluminense que o grupo teria convencido as organizações do Rio de Janeiro a venderem crack, droga à época evitada nas favelas cariocas. A parceria mais forte teria sido firmada com o CV. Essa facção estaria passando por dificuldades financeiras por ter acumulado mais de $\mathrm{R} \$ 7$ milhões de reais em dívidas com o grupo paulista, as quais foram todas perdoadas (MARTINS e JOZINO, 30/12/2013).

Seguindo o mesmo mote, a Folha de $S$. Paulo indicou novamente no ano seguinte que as imbricações entre organizações criminais se complexificaram, apontando para interlocuções entre o PCC, o CV e grupos criminosos de estados nordestinos, como o Maranhão. O efeito dessa ligação foi o aumento das rivalidades entre atores locais, gerando um caos prisional, aguçado pelas péssimas condições de privação de liberdade e torturas sistemáticas. E a imprensa não poupou detalhes sobre os episódios, descrevendo em profusão os tensionamentos entre presos com desfechos violentos, tanto que decapitações ocorridas nas prisões se tornaram narrativas comuns à época.

O retrato desses episódios ajudaria não só a alimentar sentimentos de insegurança de determinados grupos sociais, como possibilitaria processos de incriminação baseados na sujeição criminal (MISSE, 2008). Indivíduos que cometem atos como os ocorridos no Maranhão não seriam socialmente dignos de "perdão", de modo que uma vez "bandido" nesse extremo, sempre "bandido". A imprensa ajudaria a construir um rótulo atribuído ao criminoso que aparentemente não se desvencilharia tão facilmente da identidade individual, aderindo fortemente à sua subjetividade. Em boa medida, a imprensa remeteu a esse processo de expansão ao que Dias (2011) diz ser prática comum ao PCC em suas origens, quando o recurso à força era um forte instrumento de legitimação e consolidação.

São Luís, no Maranhão, deixou há três anos de ser um local em que traficantes isolados negociavam drogas para se tornar território de disputa de facções apoiadas por organizações criminosas de São Paulo e do Rio. O resultado da guerra entre os grupos PCM (Primeiro Comando do Maranhão) e Bonde dos 40 é um rastro de mortes nas ruas e dentro do presídio de Pedrinhas, o maior do Estado, onde 62 presos morreram desde 2013. Infraestrutura frágil, falta de agentes de segurança e de investimento público completam o cenário da escalada de violência no Estado. O PCC paulista e o Comando Vermelho no Rio atuam indiretamente no Maranhão. "Eles fazem uma espécie de convênio: Quem fornece a droga para vocês [faç̧ão local] sou eu", diz o subdelegado-geral do Maranhão, Marcos Afonso Júnior. "E com isso vem o armamento e a experiência que eles têm". Mais antigo e numeroso, o PCM é formado por presos 
transferidos do interior para Pedrinhas. Surgiu há dez anos, mas se consolidou há cerca de três. Copiou o nome do "padrinho" PCC, de quem recebe a droga. O contato ocorreu em 2003, quando chegaram a Pedrinhas assaltantes do Sudeste flagrados em roubos no Maranhão. Esse intercâmbio permitiu aos maranhenses entenderem como se organizava o tráfico paulista. A rixa entre capital e interior acelerou a formação do PCM (...) (COISSI, 20/01/2014).

Articulando um elemento analítico importante, o trecho acima relaciona a organização do crime em São Luís ao momento em que presos locais foram transferidos para prisões federais. Com efeito, maranhenses privados de liberdade entraram em contato com presos do PCC, passando a conhecer o código de conduta do grupo paulista.

Esse tipo de narrativa foi aprofundado em uma reportagem lançada posteriormente que indicou a tentativa do PCC de se expandir em todas as penitenciárias federais. Relatou-se uma mudança no comportamento de presos, que passaram a "desafiar" os agentes penitenciários e a adotar novas regras de comportamento, como indicado na Figura 1. Previu-se que ao menos 56 custodiados teriam se "batizado" (MARTINS, 24/11/2014). Ou seja, em um tom um pouco mais crítico em relação às políticas penais comumente executadas no país em comparação a reportagens anteriores, a Folha de S. Paulo conectou, ainda que indiretamente, o crescimento do PCC pelo Brasil e a imposição de penas mais rígidas.

Figura1: Presença de presos do PCC em penitenciárias federais

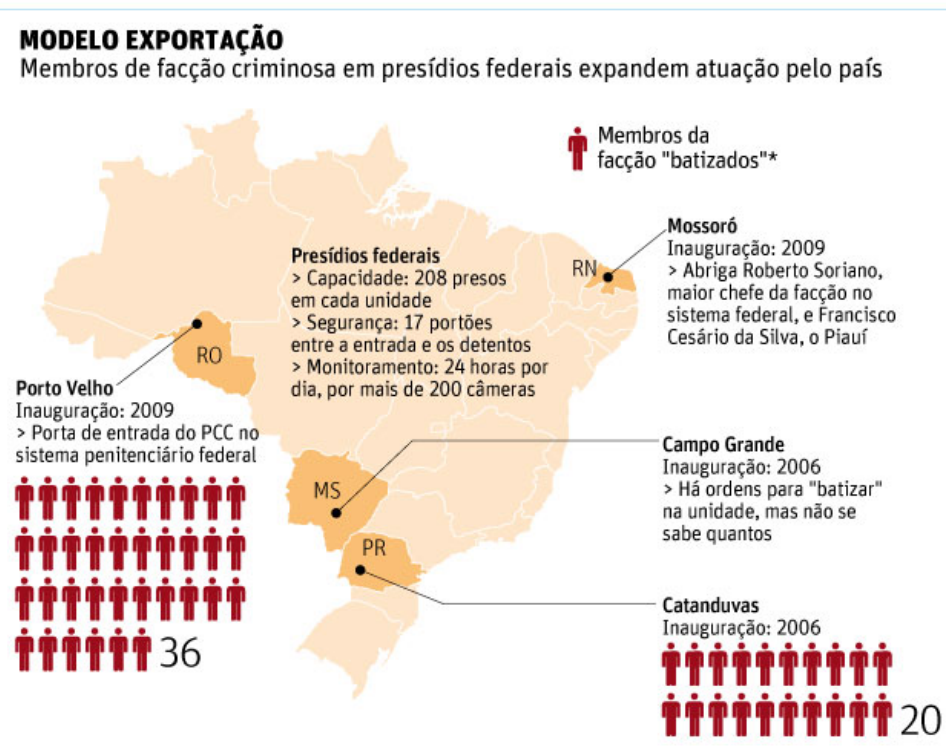

FACÇÃO OFERECE ASSISTÊNCIA NO ENTORNO DOS PRESÍDIOS

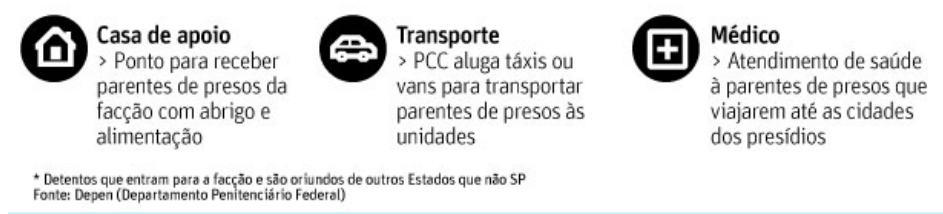

Fonte: Folha de S. Paulo - novembro de 2014. 
O veículo pareceu oscilar sua narrativa ao longo do tempo, emitindo em determinadas circunstâncias notícias mais críticas ao cenário penal estabelecido e, em outras, repertórios adstritos ao proceder tradicional do sistema de justiça criminal, voltado para a aplicação de penas mais severas e, assim, reforçando o processo de acumulação social da violência (MISSE, 1999, 2008). Essa variação pareceu depender em boa medida do cenário político desenhado quando dada matéria é divulgada, sem ignorar também o perfil do jornalista que redigiu as notícias.

Para as reportagens mais adeptas ao status quo, sobressaíram-se textos centrados em ações violentas cometidas pelo PCC, para as quais, ao menos aos olhos de determinadas notícias, se justificaria a aplicação de medidas repressivas impostas por órgãos do Estado. Incluídos nesse rol de matérias estariam os textos divulgados em 2006, que dispunham sobre possibilidade de "contaminação" do PCC a outros estados a partir de São Paulo, bem como os textos relativos às rebeliões em prisões maranhenses em 2014, centrados nas decapitações e em outras arbitrariedades cometidas pelos presos. Com abordagem similar, em 2015 a Folha de S. Paulo lançou uma matéria de capa noticiando o disparo da apreensão de crack em uma rota dominada pelo PCC na fronteira do Paraguai com o Brasil (TUROLLO JR., 18/03/2015).

Se até o momento o material disponibilizado pela imprensa indicou o estabelecimento de alianças entre o PCC e organizações de outros estados, a partir de 2015 e 2016 o cenário começou a se reconfigurar, especialmente após o assassinato do traficante Jorge Rafaat Toumani na cidade de Pedro Juan Caballero (KONIG e DYNIEWICZ, 16/06/2016). Conforme narrado pela imprensa, o ato foi cometido por membros do PCC como uma tentativa de conter o domínio do CV na área.

Diferentemente de grande parte do vulto de matérias analisado até então, a morte de Rafaat abriu flanco para uma série de textos bastante detalhados sobre o PCC e sua atuação pelo país. Em uma longa notícia denominada "Guerra na fronteira do Brasil com o Paraguai muda o controle da droga" (KONIG, 07/07/2016), a Folha de S. Paulo assinalou o quanto o município de Pedro Juan Caballero ${ }^{10}$ seria estratégico por compor uma rota entre Paraguai e Brasil. Rafaat tinha repelido várias tentativas de traficantes brasileiros de dominar a região. Após sua morte, o brasileiro Jarvis Chimenes Pavão começou a controlar o local, mesmo estando preso. Ele foi sucessor de Fernandinho Beira-Mar no CV, tendo como uma de suas funções o abastecimento de organizações criminais com cocaína boliviana e colombiana. A aliança estratégica com essas organizações tornou-o um dos principais traficantes da fronteira Brasil-Paraguai.

Pavão foi preso ainda em 2009, junto a uma liderança do PCC, Carlos Antonio Caballero, tendo ambos estreitado aliança durante a privação de liberdade. Pavão teria recebido ajuda do PCC para matar Rafaat e, com isso, começaram a dominar a área. Após esse evento, o alinhamento entre PCC e CV foi rompido, dando início a uma disputa com repercussões em todo o Brasil 
(Idem). Como consequência, grupos aliados de ambas as organizações passaram igualmente a rivalizar entre si, ensejando as já citadas rebeliões em prisões das regiões Norte e Nordeste.

\begin{abstract}
As facções criminosas Primeiro Comando da Capital (PCC), de São Paulo, e Comando Vermelho (CV), do Rio, estão em guerra pelo domínio do tráfico de drogas na fronteira do Brasil com países como Paraguai, Bolívia e Colômbia. A relação entre as duas quadrilhas, até então pacífica, vinha se desgastando nos últimos meses também por causa da disputa pelo comando do tráfico em alguns Estados. No último fim de semana, 18 presos foram mortos durante rebeliões em presídios de Boa Vista (Roraima) e Porto Velho (Rondônia) por causa da guerra (AGÊNCIA ESTADO, 19/10/2016).
\end{abstract}

Uma primeira onda de rebeliões foi deflagrada ao final de 2016 e uma segunda ocorreu em janeiro de 2017. Mais de uma centena de presos morreu nesse segundo momento, sendo ventilado pela imprensa um grande caos no sistema prisional. Os episódios foram amplamente destacados, tendo a imprensa devotado ao PCC uma forte capacidade de ação e, por sua vez, um grande poder letal:

"Maior matança em presídios desde o Carandiru deixa 56 vítimas no AM" (CHAGAS et al., 02/01/2017).

"PCC cumpre ameaça, mata 33 em Roraima e facções desafiam governo" (AGÊNCIA ESTADO, 07/01/2017).

"Rebelião no maior presídio do RN tem registro de 10 mortes" (Idem, 14/01/2017).

Os jornais foram enfáticos ao apontarem que as respostas dos governos estaduais e do Governo Federal ao episódio foram no sentido de uma maior rigidez no cumprimento da privação de liberdade, pautando medidas repressivas. Indicou-se a transferência de lideranças do PCC a prisões federais, bem como foram amplamente expostos pedidos de administrações prisionais para que os estados recebessem apoio da Força Nacional de Segurança Pública (FNSP) em seus cárceres ${ }^{11}$. O Governo Federal também publicou em janeiro de 2017 um Plano Nacional de Segurança Pública, cuja proposta baseou-se na construção e na reforma de prisões a partir do repasse de cerca de $\mathrm{R} \$ 40$ milhões a cada estado do país (KIFER, 17/01/2017).

Em síntese, o "terror" ocasionado pelo PCC, retratado tão fortemente pela imprensa, ensejaria medidas estatais que, no limite, provocariam o processo de acumulação social da violência (MISSE, 1999, 2008). A resposta dada à ação do grupo paulista se baseou na política tradicionalmente executada no Brasil, pautada pelo endurecimento penal. Essa política acaba por motivar o encarceramento em massa (SINHORETTO et al., 2013) e, por sua vez, o fomento a situações de violência nas prisões. 
Porém, com um posicionamento mais crítico, a reportagem indicada no início desta seção, publicada na Folha de S. Paulo, questionou tais medidas, afirmando que o governo de São Paulo teria ajudado a "exportar" o PCC para todo o país:

\begin{abstract}
Governo de SP "exportou" PCC para outros Estados ao transferir presos: O crescimento espantoso possui várias explicações, mas não há como ignorar o fato de que ele foi facilitado por uma polêmica política de transferência de presos perigosos. São Paulo exportou o PCC para outras regiões do país. Segundo o Ministério Público de SP, em outubro de 2014, a facção tinha cerca de 10 mil criminosos afiliados, 26\% deles fora do Estado. Hoje, quando trava uma guerra com outras quadrilhas para dominar rotas e monopolizar o tráfico de drogas no país, possui cerca de 21,5 mil "batizados", 64\% deles para além da fronteira original (GENTILE, 16/01/2017).
\end{abstract}

Na seção a seguir, descreveremos a narrativa jornalística sobre a ação desse grupo em Minas Gerais.

\title{
PCC em território mineiro?
}

A Folha de S. Paulo não mencionou qualquer relação entre o PCC e o território mineiro em nenhuma das reportagens que veiculou. $\mathrm{O}$ assunto foi abordado majoritariamente pelo jornal $O$ Tempo, de modo que a pauta se constituiu como algo mais local, de Minas Gerais, sem repercussões nacionais. Ainda assim, o tema pareceu ter caráter quase flutuante. Em alguns momentos ganhava força, em outros arrefecia. De fato, as reportagens pareceram ter dificuldades em apresentar indícios efetivos sobre a presença mais orgânica da organização em Minas Gerais nos anos iniciais da série temporal analisada. Esse dado em boa medida reforça o disposto pela literatura criminológica mineira, que não faz muitas referências sobre grupos criminosos nos moldes do PCC. Seus achados estão intimamente ligados aos homicídios referentes às décadas de 1990 e 2000, momento em que o estado experimentou um aumento crescente nos níveis de violência letal (ANDRADE e MARINHO, 2013; BATITUCCI et al., 2005; CRUZ et al., 2011) ${ }^{12}$.

Conforme Beato e Zilli (2012), metade dos homicídios em Belo Horizonte se relacionaria ao uso e venda de drogas, especialmente em territórios marcados por tráfico intenso. Boa parte das pessoas envolvidas com crimes violentos formaria gangues, compostas por jovens, negros, pobres, com baixa instrução formal, oriundos de favelas e bairros de periferia. Remetendo-se a estudos sobre ecologia do crime, os autores analisaram que as gangues seriam oriundas do crescimento desordenado e da ocupação precária do espaço. Dito de outra forma, a intensa urbanização e o adensamento populacional reverberaram em uma "favelização", em que grande parte da população ocupava um pequeno espaço comum. Esse cenário levou ao acirramento de disputas, à desorganização da mobilização social e à incapacidade de exercer controles sociais. 
Zilli (2015) discorreu sobre o tipo de socialização desenvolvido por jovens integrantes de gangues, visando compreender o processo de segregação socioespacial e a emergência de dinâmicas de violência. Os conflitos entre os jovens seriam estabelecidos e resolvidos de forma violenta em seus próprios territórios. O recurso à força não seria ferramenta tão só da resolução de conflitos; seria elemento para a constituição das identidades, tanto individuais como grupais, estruturantes de relações sociais.

Ou seja, quando existentes, os grupos criminosos mineiros atuavam especialmente na capital e na RMBH, com um tipo de proceder muito distinto do adotado pelo PCC em São Paulo. Não à toa, durante boa parte do recorte temporal estudado, o jornal $O$ Tempo apenas ventilou a possibilidade de o grupo se propagar para Minas Gerais e atuar no estado episodicamente, sem especificar como isso se desenvolveria. Nesse mote, as primeiras reportagens sobre a ação do PCC localmente remeteram ao período dos atentados cometidos pelo grupo em 2006:

"Onda de crimes em SP deixa Minas em estado de alerta" (ROCHA, 15/05/2006).

"PM reforça operações na Grande BH" (BRAGA, 17/05/2006).

"Sete acusados de ataques no Sul de Minas estão presos" (BARBOSA, 17/05/2006).

As autoridades estaduais queriam "barrar uma possível conexão da facção criminosa paulista com ramificações em todo o país com detentos de Minas Gerais" (ROCHA, 15/05/2006). Portanto, "o subsecretário de Administração Penitenciária (...) iniciou um levantamento para identificar e mapear o número de integrantes do PCC detidos em unidades prisionais mineiras" (Idem). Isto é, se falava em uma possível disseminação da organização quando o PCC estava em vias de se consolidar como grupo hegemônico em São Paulo (DIAS, 2011), compondo a prática já citada anteriormente de criminalização de novos atores e, nesse sentido, justificando ações do Estado voltadas ao uso da força. Entretanto, essa linha de matéria não demorou a se dissipar e perder espaço, parecendo que a sua veiculação se relacionou, sobretudo, a um esforço de trazer ao estado uma temática emblemática para o restante do país.

A abordagem das notícias d'O Tempo sobre a ação do PCC em Minas Gerais ao longo de 12 anos referiu-se à prisão de lideranças do grupo no sul do estado, embora não fossem discutidos elementos substantivos sobre a questão:

"Líder do PCC é preso em Minas" (GIUDICE, 31/01/2007).

"Suposto membro do PCC é preso no Triângulo" (CARVALHO, 25/03/2008).

“Traficante ligado ao PCC é preso no Triângulo Mineiro” (CAMILO, 08/01/2013). 
O Triângulo Mineiro, região próxima a São Paulo, era comumente indicado como uma rota para membros do PCC foragidos. Ainda, várias reportagens citavam tentativas de assalto a banco de autoria do grupo (CARVALHO, 02/10/2007) e apontavam o território como uma das vias para transporte de drogas.

Uma rota do tráfico de drogas que tinha como ponto final a cidade de Alfenas, no Sul de Minas, foi
desmantelada pela Polícia Civil. Ontem de manhã, foram detidas 35 pessoas. Os entorpecentes saíam da
Bolívia e, antes de chegar ao interior mineiro, passavam pelo Mato Grosso e Ribeirão Preto (SP). Nessa
última cidade, integrantes da facção criminosa paulista Primeiro Comando da Capital (PCC)
intermediavam o negócio ilícito para garantir a chegada do produto até Minas (BARBOSA, 29/10/2007).

Nessa mesma linha, em 2012 indicou-se um “Alerta contra o PCC em Minas” (FREITAS, 18/11/2012). Nessa reportagem, afirmou-se que forças de segurança pública mineiras foram advertidas sobre possíveis atentados que poderiam ser cometidos pelo grupo paulista em Minas Gerais (Idem). Por ser pouco detalhada, a notícia não indicou os motivos imagináveis da realização desses eventos, mas talvez o receio se relacionasse aos atentados orquestrados pelo grupo em São Paulo no mesmo ano (SILVESTRE, 2016). Já outra matéria lançada na mesma época apontou que o PCC teria angariado 90 novos membros em Minas Gerais, embora seu próprio texto citasse uma nota da Secretaria de Defesa Social do estado negando a informação. O poder público local afirmou deter um sistema de inteligência prisional e policial consistente que evitaria a invasão de organizações criminais em suas fronteiras (O TEMPO, 24/11/2012).

Se até o momento, ao menos publicamente, a imprensa não expunha uma posição oficial sobre a presença efetiva do PCC em Minas Gerais, em 2014 esse quadro começou em alguma medida a se transformar. Surgiram narrativas que demonstravam ações mais incisivas do poder público para conter a ação do grupo localmente. Em 2015, indicou-se haver indícios da ação do PCC em prisões mineiras. Um preso foi assassinado na penitenciária Nelson Hungria em Belo Horizonte durante o banho de sol, suspeitando-se de que a morte estivesse relacionada à disputa de poder entre membros da organização paulista (LAMEIRA, 16/02/2015). Porém, não foram fornecidos maiores detalhes sobre o contexto prisional estadual.

Já em 2017 foram veiculadas diversas matérias descrevendo o clima de caos prisional no país e as medidas adotadas pelo governo de Minas Gerais para evitar situações violentas em suas prisões. $O$ Tempo começou a divulgar citações de autoridades públicas que reconheciam a presença tanto do grupo paulista quanto do $\mathrm{CV}$ em seus estabelecimentos prisionais. A fim de mostrar presteza frente aos acontecimentos, noticiou a transferência de determinados presos e a adoção de ações de inteligência nas prisões estaduais, como a separação de pessoas privadas de liberdade pertencentes a organizações rivais. 
O secretário garantiu que não há risco iminente de episódios semelhantes aos massacres do Amazonas e de Roraima. "O sistema prisional em Minas Gerais está tranquilo, sendo monitorado, com remoções estratégicas de alguns internos, com serviço de inteligência. Não temos integrantes das facções do Norte do país em Minas, já internos do PCC e do Comando Vermelho existem em todo o sistema prisional do Brasil", disse (MIRANDA, 07/01/2017).

Talvez o poder público e a imprensa tenham avaliado que o custo político de admitir a ação mais orgânica do PCC em território mineiro não seria tão alto em 2017, haja visto o fato de ter se tornado ponto comum ao debate público a perspectiva de que o grupo teria braços por todo o país. Portanto, se antes parecia haver um esforço da imprensa local quase desmedido de trazer a pauta ao estado, mais recentemente as matérias pareceram não deixar dúvidas sobre a ação do PCC em Minas Gerais. E o fato começou a ser alimentado por citações de gestores e operadores do sistema de justiça criminal local.

\section{Considerações finais}

A proposta do artigo foi compreender como a imprensa retratou ao longo de 12 anos, de $1^{\circ}$ de janeiro de 2005 a 31 de dezembro de 2017, a propagação do PCC para fora do território paulista, em especial para Minas Gerais. De modo geral, foi possível observar que várias reportagens de ambos jornais analisados, a Folha de S. Paulo e o mineiro O Tempo, se propuseram a tocar na percepção de segurança da população, fomentando a ideia de que a criminalidade dita organizada disseminaria uma espécie de caos social, personificado, entre outros aspectos, nas múltiplas rebeliões e nas rivalidades travadas pelo grupo paulista pelo Brasil. Em boa medida, a imprensa condensaria e reforçaria a perspectiva de que organizações criminais seriam inimigos comuns da sociedade. Desse modo, se articularia como uma espécie de intérprete social, destacando a todo o momento a violência com a função de criminalizar condutas e, no limite, sujeitar indivíduos e grupos. Com efeito, a imprensa ajudaria a robustecer as relações hierárquicas que constroem todo o sistema de crenças estruturante do país, fomentando processos identificados por Misse (1999, 2008) como acumulação social da violência.

De fato, o teor das matérias ao longo do tempo foi variável e descontínuo, embora vigorasse uma perspectiva alinhada à aplicação da lei e à manutenção da ordem pública tradicionalmente estabelecida. Boa parte apresentava análises mais afeitas aos padrões de atuação do sistema de justiça criminal, reforçando as desigualdades que o perfaz. Em contrapartida, em menor número, algumas reportagens apresentavam tom mais indagativo e questionavam as políticas penais habitualmente executadas. Por outro lado, independentemente de seu teor, quase todas as matérias analisadas 
fizeram alusão a documentos e a outros dados produzidos pela polícia e pelo Ministério Público, espelhando, ainda que em certos momentos criticamente, as clivagens proferidas por tais instituições.

Como outra conclusão depreendida da análise dos jornais, não há uma narrativa linear sobre a expansão do PCC pelo Brasil. As reportagens se contradiziam entre si ao abordarem o tema, ainda que pertencessem a um mesmo veículo. No entanto, em geral, ambos os jornais considerados atribuíram grande força ao grupo, o qual era apresentado com significativa capacidade de articulação com outras organizações criminais de todo o país. Esse relato, todavia, foi relativamente distinto ao tratar de Minas Gerais. Nos anos iniciais do recorte temporal até se mencionava a presença do PCC no estado, mas de forma dispersa e inconsistente, dando mostras da baixa presença do grupo localmente. No entanto, esse discurso público se modificou a partir das rebeliões ocorridas em 2016 e em 2017, admitindo-se a presença da organização no território mineiro. Em todo o Brasil, esses eventos foram bastante explorados pelos jornais, sobretudo, o de Minas Gerais, atribuindo à organização um forte poder letal.

\section{Notas}

\footnotetext{
${ }^{1}$ Este artigo é um dos produtos da pesquisa de pós-doutorado de Thais Lemos Duarte, bolsista de pós-doutorado júnior do CNPq, realizada em parceria com a doutoranda Isabela Cristina Alves de Araújo.

${ }^{2}$ Conforme Misse (2011), será deixado de lado nas reflexões em tela o significado do que seja "crime organizado" e suas diferenças em relação às grandes quadrilhas que operam, por exemplo, com crimes contra o patrimônio. Será utilizado o que rotineiramente o senso comum e a imprensa identificam por "crime organizado".
}

${ }^{3}$ Nesse escopo, compreende-se "violência" como uma espécie de operador analítico de caráter polissêmico, devendo ser analisada como categoria nativa, como representações de práticas muito variadas, de interações e de conflitos sociais complexos.

${ }^{4} \mathrm{O}$ grau no qual um ato será rotulado como desviante depende de quem o comete e de quem se ofende diante dele. Conforme Becker (1971), as regras tendem a ser aplicadas mais a certas pessoas que a outras, porque a imposição das normas sociais está relacionada às características dos seus destinatários. O desvio seria, então, uma transação desenvolvida por um grupo social que analisa determinado indivíduo como transgressor das regras.

5 Conferir, respectivamente, os sites de ambos os jornais: https://acervo.folha.com.br/index.do; https://www.otempo.com.br/

${ }^{6}$ Segundo Silvestre (2016), em 1994 havia 43 unidades prisionais sob a administração da Secretaria de Estado de Administração Penitenciária (Seap). Em 2016, esse número chegou a 164, sendo que 127 foram construídas a partir de 1995. 78\% das unidades foram inauguradas em oito anos, de 1998 a 2005.

${ }^{7}$ Procedimento investigatório criminal n 336/10 do Ministério Público de São Paulo. O presídio, também conhecido como Piranhão, foi inaugurado nos anos 1980 e era uma espécie de castigo a presos indisciplinados, com visitas e banhos de sol restritos. Além desses controles oficiais, a unidade era conhecida por arbitrariedades no trato dos presos, sistematicamente vítimas de tortura (DIAS, 2011).

${ }^{8}$ O RDD, disposto no artigo n 52 da Lei de Execução Penal (LEP), é uma forma especial de cumprimento da pena no regime fechado, que consiste na permanência da pessoa privada de liberdade (provisório ou condenado) em cela individual, com limitações do direito de visita e de saída da cela.

${ }^{9}$ O primeiro presídio federal surgiu em 2006 no Paraná, chamado de Penitenciária Federal de Catanduvas. Atualmente há quatro presídios federais no país: além de Catanduvas, há a Penitenciária Federal de Campo Grande, a Penitenciária Federal de Porto Velho e a Penitenciária Federal de Mossoró.

${ }^{10}$ Município paraguaio situado na fronteira com o Brasil no Mato Grosso do Sul. 
${ }^{11}$ A FNSP é um programa de cooperação entre os estados-membros e a União Federal, a fim de executar, por meiode convênio, atividades e serviços voltados à "preservação da ordem pública, à segurança das pessoas e do patrimônio", atuando também em situações de emergência e calamidades públicas. Informações disponíveis (on-line) em: https://www.justica.gov.br/news/collective-nitf-content-1546630482.88

${ }^{12}$ Conforme Cruz et al. (2011), entre 1995 e 2003 os crimes violentos cresceram 400\% em Minas Gerais, ao passo que os roubos aumentaram $581 \%$ e os homicídios subiram $96 \%$. Observou-se um crescimento desigual de criminalidade, de modo que apenas a capital, Belo Horizonte, concentrou $41 \%$ de toda a criminalidade violenta do estado. Batitucci et al. (2005) apontam para dois fenômenos que teriam influenciado esse incremento nos níveis de criminalidade: em primeiro lugar, a concentração das ocorrências de homicídio em certos municípios mineiros em detrimento de outros; em segundo, enquanto algumas cidades com altas taxas de homicídios vinham apresentando quedas em seus níveis de violência letal, grandes municípios e seus entornos exibiam aumentos significativos. Nesse sentido, para Andrade e Marinho (2013) haveria uma disseminação dos homicídios para o interior de Minas Gerais, porém com maior gravidade no ambiente metropolitano. A concentração da violência letal não teria relação com o crescimento da população, mas com a urbanização adensada e a grande concentração territorial de indivíduos (BEATO e ZILLI, 2012). 


\section{Referências}

ADORNO, Sérgio; DIAS, Camila Nunes. "Cronologia dos 'Ataques de 2006' e a nova configuração de poder nas prisões na última década”. Revista Brasileira de Segurança Pública, São Paulo vol. 10, n. 2, pp. 118-132, 2016.

ANDRADE, Luciana Teixeira de; MARINHO, Marco Antônio Couto. "Organização social do território e violência letal na Região Metropolitana de Belo Horizonte: O balanço de uma década”. In: Homicídios nas regiões metropolitanas. Rio de Janeiro: Letra Capital, 2013.

BATITUCCI, Eduardo Cerqueira; CRUZ, Marcus Vinicius Gonçalves da; RIBEIRO, Ludmila Mendonça Lopes. Criminalidade violenta na região metropolitana de Belo Horizonte (RMBH): Reflexos nas políticas de segurança. Trabalho apresentado no XII Congresso Brasileiro de Sociologia, Belo Horizonte, MG, 31 de maio a 03 de junho de 2005.

BEATO, Cláudio; ZILLI, Luís Felipe. "A estruturação de atividades criminosas: Um estudo de caso". Revista Brasileira de Ciências Sociais, vol. 27, n.80, pp. 71-88, 2012.

BECKER, Howard S. Los extraños: Sociología de la desviación. Buenos Aires: Tiempo Contemporáneo, 1971.

BIONDI, Karina. Junto e misturado: Uma etnografia do PCC. São Paulo: Terceiro Nome, 2010.

CANO, Ignacio; ALVADIA, Alberto. Análise dos impactos dos ataques do PCC em São Paulo em maio de 2006. Laboratório de Análise de Violência e Conectas Direitos Humanos, São Paulo, 2008.

CARVALHO, Denise W.; FREIRA, Maria Teresa; VIILAR, Guilherme. "Mídia e violência: Um olhar sobre o Brasil”. Revista Panam Salud Publica, vol. 31, n. 5, pp. 435-438, 2012.

CHRISTINO, Márcio Sérgio. Por dentro do crime: Corrupção - Tráfico - PCC. São Paulo: Fiúza Editores, 2001.

COELHO, Edmundo Campos "A criminalização da marginalidade e a marginalização da criminalidade”. Revista de Administração Pública, vol. 12, n. 2, pp. 139-161, 1978.

CRUZ, Marcus Vinicius Gonçalves da; BATITUCCI, Eduardo; PEIXOTO, Betânia; GODINHO, Letícia; SOUSA, Rosânia Rodrigues de; SILVA, Sérgio Felix da. Criminalidade em Belo Horizonte: Notas para discussão. Belo Horizonte: Fundação João Pinheiro, 2011.

DIAS, Camila. Da pulverização ao monopólio da violência: Expansão e consolidação do Primeiro Comando da Capital (PCC) no sistema carcerário paulista. Tese (Doutorado em Sociologia) - Universidade de São Paulo, São Paulo, 2011.

DIAS, Camila; MARQUES, Maria Gorete; NATAL, Ariadne; POSSAS, Mariana; RUOTTI, Caren. “A prática de execuções na região metropolitana de São Paulo na crise de 2012: Um estudo de caso". Revista Brasileira de Segurança Pública, vol. 9, n. 2, pp. 160-179, 2015.

FELTRAN, Gabriel. "Crime e castigo na cidade: Os repertórios da justiça e a questão do homicídio nas periferias de São Paulo”. Caderno CRH, vol. 23, pp. 59-74, 2010.

FELTRAN, Gabriel. "Sobre anjos e irmãos: Cinquenta anos de expressão política sobre o crime numa tradição musical das periferias”. Revista do Instituto de Estudos Brasileiros, n. 56, pp. 43-72, 2013. 
LOURENÇO, Luiz Claudio; DIAS, Camila Nunes. Discutindo elementos para a definição e a atuação de coletivos de internos do sistema prisional de São Paulo e da Bahia. Trabalho apresentado no $39^{\circ}$ Encontro Anual da Anpocs, Caxambu, 2015.

MARQUES, Adalton. Crime, proceder, convívio-seguro: Um experimento antropológico partir de relações entre ladrões. Dissertação (Mestrado em Antropologia) - Universidade de São Paulo, São Paulo, 2009.

MISSE, Michel. Malandros, marginais e vagabundos \& a acumulação social da violência no Rio de Janeiro. Tese (Doutorado em Sociologia) - Instituto Universitário de Pesquisas do Rio de Janeiro, Rio de Janeiro, 1999.

MISSE, Michel. "Sobre a acumulação social da violência no Rio de Janeiro". Civitas, Porto Alegre, vol. 8, n. 3, p. 371-385, 2008.

MISSE, Michel. "Crime organizado e crime comum no Rio de Janeiro: Diferenças e afinidades". Revista de Sociologia e Política, Curitiba, vol. 19, n. 40, pp. 13-25, 2011.

OLIVEIRA, Victor Neiva; BASTOS, Luiza Meira; RIBERO, Ludmila Mendonça Lopes.Pavilhões do Primeiro Comando da Capital - PCC: Ramificação e expansão da organização criminosa em Minas Gerais?. 18 Congresso Brasileiro de Sociologia, Brasília (DF), 26 a 29 de julho de 2017.

PASTORAL CARCERÁRIA. Tortura em tempos de encarceramento em massa. São Paulo: Asaac, 2016.

SALLA, Fernando; DIAS, Camila Nunes; SILVESTRE, Giane. "Políticas penitenciárias e as facções criminosas: Uma análise do regime disciplinar diferenciado (RDD) e outras medidas administrativas de controle da população carcerária”. Estudos Sociológicos, Araraquara, vol. 17, n. 33, pp. 333-351, 2012.

SILVESTRE, Giane. Enxugando o iceberg: Como as instituições estatais exercem o controle do crime em São Paulo. Tese (Doutorado em Sociologia) - Universidade Federal de São Carlos, São Carlos, 2016.

SINHORETTO, Jacqueline; SILVESTRE, Giane; MELO, Felipe Athayde Lins de. "O encarceramento em massa em São Paulo”. Tempo Social, Revista de Sociologia da USP, São Paulo, vol. 25, n. 1, pp. 83-106, 2013.

ZILLI, Luís Felipe. "O 'mundo do crime' e a 'lei da favela': Aspectos simbólicos da violência de gangues na região metropolitana de Belo Horizonte”. Etnográfica, vol. 19, n. 3, pp. 463-487, 2015.

Fontes da imprensa

AGÊNCIA ESTADO. "PCC e CV travam guerra pelo domínio do trágico nas fronteiras: No último fim de semana, 18 presos foram mortos durante rebeliões em presídios de Boa Vista (Roraima) e Porto Velho (Rondônia) por causa da guerra”. O Tempo, Capa, Brasil, Quadrilhas, 19 out. 2016. Disponível em: https://www.otempo.com.br/capa/brasil/pcc-e-cv-travam-guerra-pelodom\%C3\%ADnio-do-tr\%C3\%A1fico-nas-fronteiras-1.1387464 
AGÊNCIA ESTADO. "PCC cumpre ameaça, mata 33 em Roraima e facções desafiam governo: Os assassinos filmaram as execuções ocorridas na madrugada dessa sexta-feira (6) e distribuíram o vídeo pelo WhatsApp". O Tempo, Brasil, 07 jan. 2017. Disponível em: https://www.otempo.com.br/capa/brasil/pcc-cumpre-amea\%C3\%A7a-mata-33-em-roraima-efac\%C3\%A7\%C3\%B5es-desafiam-governo-1.1420381

AGÊNCIA ESTADO. "Rebelião no maior presídio do RN tem registro de 10 mortes: Segundo a assessoria do governo estadual, trata-se de uma disputa entre as facções Primeiro Comando da Capital (PCC) e Sindicato do Crime RN”. O Tempo, Brasil, 14 jan. 2017. Disponível em: https://www.otempo.com.br/capa/brasil/rebeli\%C3\%A3o-no-maior-pres\%C3\%ADdio-dorn-tem-registro-de-10-mortes-1.1423423

BÄCHTOLD, Felipe. "Facção pode ter ordenado ataques em Santa Catarina: Ação de grupo teria sido motivada por supostos maus-tratos em presídio". Folha de S. Paulo, Cotidiano, 19 nov. 2012. Disponível em: http://www1.folha.uol.com.br/fsp/cotidiano/78885-faccao-pode-terordenado-ataques-em-santa-catarina.shtml

BARBOSA, Lívio. "Sete acusados de ataques no Sul de Minas estão presos". O Tempo, Brasil, 17 mai. 2006. Disponível em: https://www.otempo.com.br/brasil/sete-acusados-de-ataques-nosul-de-minas-estao-presos-1.294277

BARBOSA, Lívio. "PCC serve de ponte ao tráfico mineiro: Quadrilha de Alfenas contava com grupo paulista para garantir droga da Bolívia; 35 integrantes do bando foram presos”. O Tempo, Cidades, 29 out. 2007. Disponível em: https://www.otempo.com.br/cidades/pccserve-de-ponte-ao-trafico-mineiro-1.304067

BRAGA, Ernesto. "PM reforça operações na Grande BH: Foram realizadas blitze nas saídas da cidade e operações na região Norte; fronteira com SP continua sob vigília". O Tempo, Brasil, 17 mai. 2006. Disponível em: https://www.otempo.com.br/brasil/pm-reforca-operacoes-nagrande-bh-1.294688

CAMILO, José Vítor. "Traficante ligado ao PCC é preso no Triângulo Mineiro". O Tempo, Cidades, 08 jan. 2013. Disponível em: https://www.otempo.com.br/cidades/traficante-ligadoao-pcc-e-preso-no-triangulo-mineiro- 1.225353

CARVALHO, Sandra. "PM frustra ação do PCC em Januária”. O Tempo, Cidades, 02 out. 2007. Disponível em: https://www.otempo.com.br/cidades/pm-frustra-acao-do-pcc-em-januaria1.305269

CARVALHO, Sandra. "Suposto membro do PCC é preso no Triângulo". O Tempo, Cidades, 25 mar. 2008. Disponível em: https://www.otempo.com.br/cidades/suposto-membro-do-pcc-epreso-no-triangulo- 1.293588

CHAGAS, Bruna; MAIA, Dhiego; MAISONNAVE, Fabiano; NEVES, Fernanda Pereira. "Maior matança em presídios desde o Carandiru deixa 56 vítimas no AM”. Folha de S. Paulo, Cotidiano, 02 jan. 2017. Disponível em: https://m.folha.uol.com.br/cotidiano/2017/01/1846359-maior-matanca-empresidios-desde-o-carandiru-deixa-56-vitimas-no-am.shtml

COISSI, Juliana. "Pedrinhas sem controle: Presídio no Maranhão onde presos foram decapitados é disputado por 4 facções criminosas”. Folha de S. Paulo, Cotidiano, 20 jan. 2014. Disponível em: http://www1.folha.uol.com.br/fsp/cotidiano/148561-pedrinhas-sem-controle.shtml 
FREITAS, Rodrigo. “Alerta contra o PCC em Minas”. O Tempo, Cidades, 18 nov. 2012. Disponível em: https://www.otempo.com.br/cidades/alerta-contra-o-pcc-em-minas-1.259721

GENTILE, Rogério. “Governo de SP 'exportou' PCC para outros Estados ao transferir presos”. Folha de S. Paulo, Cotidiano, 16 jan. 2017. Disponível em: http://www1.folha.uol.com.br/cotidiano/2017/01/1850133-governo-de-sp-exportou-pccpara-outros-estados-ao-transferir-presos.shtml

FOLHA DE S. PAULO. “Apuração mostra negócios entre facções de Rio e SP”. Folha de S. Paulo, Cotidiano, 26 nov. 2011. Disponível em: https://www1.folha.uol.com.br/fsp/cotidian/11290apuracao-mostra-negocios-entre-faccoes-de-rio-e-sp.shtml

FOLHA DE S. PAULO. "Facção criou rede de tráfico no exterior: Criminosos do PCC eliminaram atravessadores e trazem do Paraguai e da Bolívia drogas para o mercado nacional. Segundo investigações, facção também se associou a traficantes internacionais para vender para a Europa". Folha de S. Paulo, Cotidiano, 19 dez. 2011. Disponível em: http://wwwl.folha.uol.com.br/fsp/cotidiano/15787-faccao-criou-rede-de-trafico-noexterior.shtml

FOLHA DE S. PAULO. “Crime cresce em SC com a migração de quadrilhas: Crime cresce em SC com a migração de quadrilhas. Para sociólogo, Estado vive efeito da interiorização da criminalidade. Governo catarinense não comenta se existe ligação dos atentados no Estado com o PCC ou com ataques em SP”. Folha de S. Paulo, Cotidiano, 18 nov. 2012. Disponível em: http://wwwl.folha.uol.com.br/fsp/cotidiano/78688-crime-cresce-em-sc-com-a-migracao-dequadrilhas.shtml

GENTILE, Rogério. “Governo de SP 'exportou' PCC para outros estados ao transferir presos”. Folha de S. Paulo, Cotidiano, Massacre em presídios, 16 de janeiro de 2017, em Folha de São Paulo. Disponível em: http://www1.folha.uol.com.br/cotidiano/2017/01/1850133-governode-sp-exportou-pcc-para-outros-estados-ao-transferir-presos.shtml

GIUDICE, Patricia. "Líder do PCC é preso em Minas". O Tempo, Cidades, 31 jan. 2007. Disponível em: https://www.otempo.com.br/cidades/lider-do-pcc-e-preso-em-minas-1.317625

KIFER, Camila. "Temer se reunirá com governadores em assinatura do Plano de Segurança: Um dia antes do encontro, que deve ocorrer nesta quarta (18), o ministro da Justiça, Alexandre de Moraes, deve se reunir com os secretários de segurança pública estaduais para finalizar as orientações de contenção da violência”. O Tempo, Em Brasília, 17 jan. 2017. Disponível em: https:/www.otempo.com.br/capa/pol\%C3\%ADtica/temer-se-reunir\%C3\%A1-comgovernadores-em-assinatura-do-plano-de-seguran\%C3\%A7a-1.1424229

KONIG, Mauri; DYNIEWICZ, Luciana. “Batalha militar' de 4h mata brasileiro chefe do tráfico na fronteira paraguaia”. Folha de S. Paulo, Cotidiano, 16 de junho de 2016. Disponível em: http://www1.folha.uol.com.br/cotidiano/2016/06/1782346-brasileiro-chefe-do-trafico-nafronteira-com-o-paraguai-e-morto-em-tiroteio.shtml

KONIG, Mauri. "Guerra na fronteira do Brasil com o Paraguai muda controle da droga”. Folha de S. Paulo, Guerra, 07 jul. 2016. Disponível em: http://temas.folha.uol.com.br/guerra-nafronteira/guerra/guerra-na-fronteira-do-brasil-com-o-paraguai-muda-controle-da-droga.shtml 
LAMEIRA, Gustavo. "Detento é morto durante banho de sol na Nelson Hungria: Suspeita é que execução esteja relacionada com a facção criminosa PCC (Primeiro Comando da Capital)". O Tempo, Cidades, 16 fev. 2015. Disponível em: https://www.otempo.com.br/cidades/detentoe-morto-durante-banho-de-sol-na-nelson-hungria-1.995004

MARTINS, Marco Antônio; JOZINO, Josmar. "Facção criminosa paulista gerencia negócios do crime no Rio". Folha de S. Paulo, Cotidiano, Rio de Janeiro, 30 dez. 2013. Disponível em: http://www1.folha.uol.com.br/cotidiano/2013/12/1391427-faccao-criminosa-paulistagerencia-negocios-do-crime-no-rio.shtml

MARTINS, Marco Antônio. "Facção criminosa se articula em presídios federais no país". Folha de S. Paulo, Cotidiano, 24 nov. 2014. Disponível em: http://www1.folha.uol.com.br/cotidiano/2014/11/1552289-faccao-criminosa-se-articula-empresidios-federais-no-pais.shtml

MIRANDA, Bernardo. "Não há plano de contingência para presídios de Minas Gerais: Governo do Estado informou que a situação "está tranquila e monitorada" em suas unidades". O Tempo, Cidades, 07 jan. 2017. Disponível em: https://www.otempo.com.br/cidades/nao-ha-plano-decontingencia-para-presidios-de-minas-gerais-1.1420306

O TEMPO. "Rio se prepara para 'contágio"”. O Tempo, Brasil, 16 mai. 2006. Disponível em: https://www.otempo.com.br/capa/brasil/rio-se-prepara-para-contagio-1.294701

O TEMPO. "PCC realizou 'batismos' de 90 novos integrantes em Minas: Governo mineiro contesta relatório federal e nega presença no Estado”. O Tempo, Brasil, 24 nov. 2012. Disponível em: https://www.otempo.com.br/capa/brasil/pcc-realizou-batismos-de-90-novosintegrantes-em-minas-1.360928

ROCHA, Murilo. "Onda de crimes em SP deixa Minas em estado de alerta: Ramificações da facção criminosa paulista em Minas, obrigam governo mineiro a traçar plano de emergência”. $\mathbf{O}$ Tempo, Cidades, 15 mai. 2006. Disponível em: https://www.otempo.com.br/cidades/onda-decrimes-em-sp-deixa-minas-em-estado-de-alerta-1.329465

TUROLLO JR., Reynaldo. “Apreensões de crack disparam em conexão paraguaia do PCC: Polícia Rodoviária Federal já apreendeu neste ano na região mais do que em 2014 inteiro. Polícia de SP suspeita que facção tenha mudado estratégia e investido na droga de olho na demanda". Folha de S. Paulo, Cotidiano, 18 mar. 2015. Disponível em: https://feeds.folha.uol.com.br/fsp/cotidiano/212330-apreensoes-de-crack-disparam-emconexao-paraguaia-do-pcc.shtml

THAIS LEMOS DUARTE (thais-duarte@hotmail.com) é pesquisadora de pós-doutorado no Programa de Pós-Graduação em Sociologia (PPGS) da Universidade Federal de Minas Gerais (UFMG, Belo Horizonte, Brasil), bolsista de pósdoutorado júnior do CNPq. Tem doutorado pelo Programa de Pós-Graduação em Ciências Sociais (PPCIS) da Universidade do Estado do Rio de Janeiro (Uerj, Brasil), mestrado pelo 
Programa de Pós-Graduação em Sociologia e Antropologia (PPGSA) da Universidade Federal do Rio de Janeiro (UFRJ) e graduação em ciências sociais pela Uerj.

(iD) https://orcid.org/0000-0002-9149-7387

ISABELA CRISTINA ALVES DE ARAÚJO (isabelacristina1903@gmail.com) é doutoranda do Programa de Pós-Graduação em Sociologia (PPGS) da Universidade Federal de São Carlos (UFSCar, Brasil). Tem mestrado pelo PPGS da UFMG e graduação em ciências sociais pela mesma universidade.

(iD) https://orcid.org/0000-0002-2526-4825

Recebido em: 28/01/2019

Aprovado em: 05/08/2019 